\title{
Monitoring System of Sustainable Development in Cultural and Mountain Tourism Destinations
}

\author{
- Jurigová Zuzana, Lencsésová Zuzana
}

\begin{abstract}
Tourism destinations are vulnerable to negative impacts of tourism development and thus require a sustainable approach. It is significant mainly in destinations with fragile environments such as cultural destinations with their historical value and mountain destinations with specific natural conditions. The aim of this paper is to propose the monitoring system for sustainable development of cultural and mountain destinations based on the critical scientific literature review. The added value of this work resides in defining specific indicators (creating monitoring system) for measurement of sustainability in cultural routes and mountain destinations.
\end{abstract}

Keywords: sustainability, indicator, measurement, tourism destination, destinations, mountain destination

JEL Classification: $L 83$

\section{INTRODUCTION}

Contemporary situation of dynamically growing tourism sector urges us to deal with the theme of possible preservation of tourism sources for future generations. Because tourism is an open system, everyone has a freedom to enter it as well as share its benefits. However this openness of the system may cause negative effects that need to be restricted. Thus sustainability of tourism is one of the most discussed themes which are debated by many domestic and foreign authors who pay attention to it. General description of the need for sustainability in tourism led us to an idea to cover certain areas in tourism. This work provides for monitoring system how to evaluate the sustainability of destinations. From a vast number of types of destinations (urban, cultural, mountain, spa etc.), we have decided to apply indicators for measuring sustainability of two specific destinations, i.e. cultural and mountain destinations due to their unique environment. Theoretically there exist a vast range of indicators discovered and subsequently described by many authors; however each type of tourism destination is unique. Therefore it is necessary to reconsider the usage of indicators for specific areas and take into account the character and peculiarities of every type of destination and its management.

\section{THEORETICAL SOLUTIONS}

\subsection{Development of Tourism Sustainability}

One of the basic assumptions of tourism development is the balance of the country. Tourism develops when there are natural, cultural or historical monuments and where as yet there has been no disruption of the balance between the elements of the environment. Therefore various literature sources depict the necessity of sustainable tourism and describe its beginnings and 
development. The substance of sustainable development was first mentioned in the report of the World Commission on Environment and Development (Our Common Future, 1987). In this report sustainable development is defined as: "That development meets the needs of the present without compromising the ability of future generations to meet their own needs" (Our Common Future, 1987). Since its adoption, Governments, NGOs and scientists have expanded the definition of sustainable development for the needs of the various sectors of the economy, among them also tourism This document was followed up by the United Nations, which in 1992 hosted an International Earth Summit in Rio de Janeiro. The conference resulted into the strategy Agenda 21, according to which the essence of sustainable development is the quality of life, reduction of the risk to the environment and maintaining the continuous use of renewable resources.

Based on general starting points of sustainable development in 1992, the creation of the set of principles for sustainable tourism was proposed by World Wildlife Fund and Tourism Concern as following: (United Nations Sustainable Development, 1992)

- using resources sustainable,

- reducing over-consumption and waste,

- maintaining diversity,

- integrating tourism into planning,

- supporting local economies,

- involving local communities,

- consulting stake holders and the public,

- training staff,

- marketing tourism responsibly,

- undertaking research.

Sustainable tourism is one of the approaches to the development of the tourism sector, which should assist the decision-maker in tourism to best balance its positive and negative effects on current and future population (United Nations, 2001).

The positive effects of tourism include tourism revenues, value creation and multiplier effect, its contribution to foreign exchange earnings and other non-economic (environmental, social and cultural) effects. The negative effects of tourism are seen in its uncoordinated development, price increases, crime, etc.

The sustainable development of tourism belongs currently to the most discussed issues. In the definitions that identify the substance of sustainable tourism (Garrod \& Fyall, 1998; Sharpley, 2000; Pforr, 2001; Hardy, Beeton \& Pearson, 2002; Farell \& Twining-Ward, 2005; Sheehan, Ritchie, 2005; UNWTO, 2005; Byrd, 2007; Bramwell \& Lane, 2010; Gúčik, 2010; Global Tourism Sustainable Council, 2012, Kučerová, 2012) are two essential elements that are on the one hand the limits of the environment (finite resources) and on the other hand the human needs (needs of enterprises and society). The main task is then meeting the visitors' and locals' needs 
whilst respecting the environment. Concluding the various approaches to sustainable tourism development we come to the conclusion that it stands on three pillars. The first one is to ensure economic benefits for the tourism destination (economic efficiency), then the well-being of local residents (corporate social responsibility) and minimal environmental impacts (environmental sustainability).

When defining the essence of sustainable tourism development, the focusing only on the supply side is insufficient. It is also necessary to take into account the behavior of visitors (demand side). OECD (2002) defines the sustainable consumer behavior as social, economic and political activities aimed at consumption of such goods and services that contribute to a better quality of life while minimizing the waste production, use of natural resources, toxic materials and emissions that do not threaten meeting the needs of future generations.

Following the above, we can conclude that the sustainable tourism development is one which raises awareness of visitors, local business owners and locals about the natural, cultural and historical potential, while ensuring the protection and increased respect for the natural, social and cultural backgrounds of the destination, and the result should be an experience for the visitor and his satisfaction.

\subsection{Indicators for Sustainable development}

As UNWTO defined sustainability as "more important than ever" in its brochure Tourism Towards 2013 Global Overview, it is necessary to define concrete principles on which each type of tourism would function in order to preserve uniqueness of destination and its treasures for future generations. (UNWTO, 2012) The providers of tourism services dealing with sustainability struggle with abstract concept of sustainability (e.g. Moldan, 2003) This vague concept brought specialists and experts to the conclusion that for practical use the sustainability needs to be supported by measurement through various sustainability indicators.

The measurement of sustainability is required due to several reasons. Except of abstractness of this term, European Commission states aspects which are included in the term of sustainability, i.e. "the responsible use of natural resources, taking account of the environmental impact of activities (production of waste, pressure on water, land and biodiversity, etc.), the use of clean energy, protection of heritage and preservation of the natural and cultural integrity of destinations, the quality and sustainability of jobs created, local economic fallout or customer care." (European Union, 2013 p.8) Simultaneously the previously mentioned impacts can be taken as an argument for the necessity of development of indicators. In all mentioned aspects the sustainability needs to be measured in order to prevent economic, social and ecological environment from negative effects. Rio \& Nunes (2012) support this assertion by claiming that "monitoring and evaluation of the impact of tourism on the tourism destinations are indispensable to guarantee a long- term sustainability of the destinations."

For these purposes a system of indicators used for measurement of sustainability was determined and implemented. The first reference to sustainability was presented by United Nations as early as 1992. Document Agenda 21 set the need for measurement of sustainability as a source for adequate data and information about sustainability. Authors of Agenda 21 claim that monitoring and evaluation of proceeding toward sustainable development is inevitable due to the fact 
that "adopting indicators that measure changes across economic, social and environmental dimensions" determine "solid bases for decision- making at all levels" and "contributes to a self - regulating sustainability of integrated environment and development systems". (United Nations Sustainable Development, 1992) United Nations depicted important issue for businesses because they perceived challenges and changes in the society and recognized them as impulse for establishing sustainability indicators. However except for objectives, promotion or ways of implementation, Agenda 21 has not designed any concrete indicator system for measurement.

Not until 1996, the appropriate collection of sustainability indicators and its testing was made. In 1996 United Nations issued methodology titled "Indicators of Sustainable Development: Framework and Methodologies". (Daly, 1996) Building on this methodology, governments launched a project of its testing in practice and a simple model of indicators based on GDP resulted from this framework. For instance, some of the indicators used for measurement of economic performance were "GDP per Capita, Investment Share in GDP, Balance of Trade in Goods and Services, Debt to GNP Ratio, Total ODA Given or Received as a Percent of GNP”. (Division for Sustainable Development, 2001) GDP is used in everyday reality for sustainability measurement, however many authors claim that it is not relevant source of data as it does not capture sustainability measurement in all aspects (Nováček, 2010 or Bossel, 1999). Concentrating on the Czech Republic, sustainable development is defined in law no 17/1992 Coll. in paragraph 6, as a development that preserves basic life requirements along with a non-decrease of nature variety and preserves natural functions of ecosystems. (Zákon č. 17/1992 Sb. o životním prostředí, 1991) According to the Annual Tourism Report 2012, governmental bodies in the Czech Republic such as the Ministry of Agriculture, the Ministry of the Environment or the Ministry of Culture along with non-governmental organisations such as the Greenways or local associations such as the Regional Brands Association or Czech Inspiration participate in the development of sustainability at the national level. (European Commission, 2013)

More critical and practical measurement system in European tourism was developed by European Commission. It introduces a system of indicators as a tool for measuring sustainability, too. Its system called "European Tourism Indicator System" applied to tourism destinations is an intentionally designed tool for monitoring sustainability. European Commission divides indicators on core and optional into four sections namely Destination Management, Economic Value, Social and Cultural Impact and Environmental Impact. Core indicators are aimed at sustainability of tourism and are taken as an initial step for measurement of the sustainability level. Optional indicators emphasize sustainability systems more advanced and relevant to destinations. (European Union, 2013)

Except for government bodies and tourism organizations many authors like Bossel (1999), Lawn (2006), Roberts \& Tribe (2008), Ngamsomsuke et al. (2011), Lozano-Oyola et al., (2012), Rio \& Nunes (2012) and others stress the importance of sustainability measurement by usage of indicators. For instance, Lozano- Oyola et al. (2012) claims that it is "a common practice to use an indicator system for designing and implementing tourism models" with focus on sustainability. Similarly numbers of studies describe indicators and its usefulness as a measurement and planning tool of tourism sustainability due to the fact that it is an open system with possible adoptions of different frameworks. Bell \& Morse (2008), Waldron \& Williams (2002), Butler (1998) discussed 
importance of sustainability indicators. For instance Butler argues that the term sustainability is "meaningless" without implementing indicators as measurement tools. (Butler, 1998).

\section{OBJECTIVES AND METHODOLOGY}

The aim of the paper is to propose the monitoring system for sustainable development of cultural and mountain destinations based on the critical scientific literature review. Firstly, literature review on sustainability and its measurement needed to be compiled in order to give quality foundation for practical solutions. Subsequently based on the characteristic of chosen types of tourism destinations, the set of indicators creating the monitoring system will be proposed. Considering the fact that it is necessary to monitor given indicators in time and draw a comparison of indicators' development, the aim of the work is not supported by the concrete figures in certain areas.

Following graph describes the sequence of steps needed to be done in order to propose suitable sustainability indicators for cultural routes and mountain destinations.

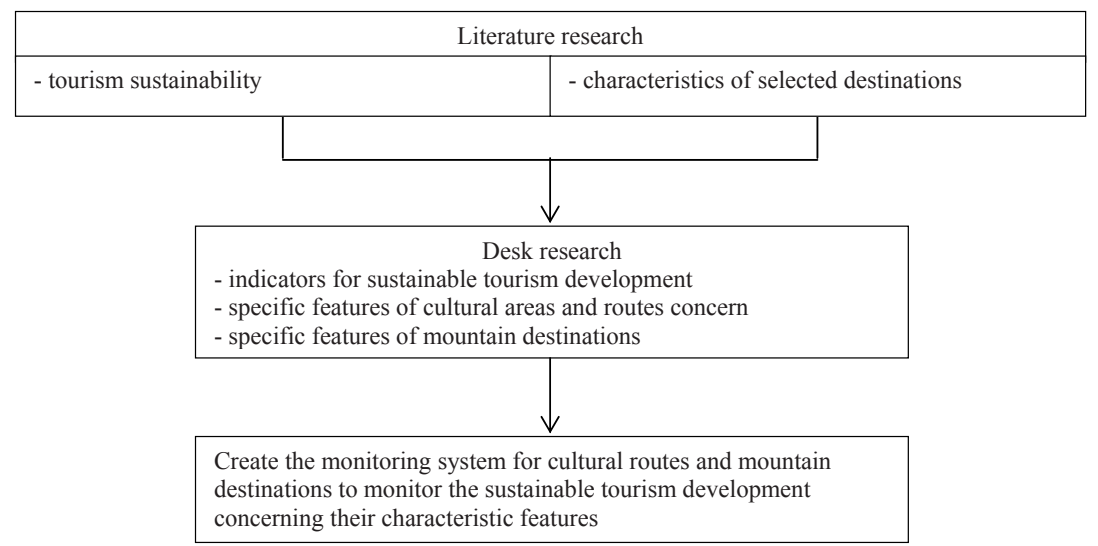

Fig. 1 - Methodology for creating a monitoring system. Source: own processing.

The created monitoring system can be used in following basic areas of application to:

- monitor sustainable tourism development,

- compare destinations with other competing destinations in terms of sustainability,

- guide management of destinations about further development with respect to sustainability,

- initiate a discussion within tourism stakeholders about long-term development.

\section{RESULTS AND DISCUSSION}

Cultural and mountain destinations as specific types of tourism destinations succumb to many external influences, either positive or negative. Thus in order to prevent cultural heritage and 
natural conditions for future generations, it is vital to set a system of sustainable indicators that should be used for setting sustainable rules in tourism.

\subsection{Characteristic features of cultural areas concern to sustainable development}

Characteristic attributes of cultural destinations and its importance are portrayed in many publications written by experts on sustainable tourism. For instance Craik (1995), Stebbins (1996), New World Hope Organization, (1999), Coccossis (2008) and others mention various characteristics of cultural tourism However, all of them mention importance of culture, its heritage and local resources in tourism. Stebbins (1996), for instance, defines culture interconnected with tourism as "a genre of special interest tourism based on the search for and participation in new and deep cultural experiences, whether aesthetic, intellectual, emotional, or psychological". Aydin's depiction of cultural tourism is similar to Stebbins assertion however his characteristic of cultural tourism is more detailed. According to Aydin, all touristic activities with the aim of art, knowledge of cultural values and historical areas connected with certain culture are covered in the term cultural tourism. (Seçkin Eser et al., 2013) Culture is thus perceived as a route to our history. Council of Europe in its study on Sustainable Cultural Tourism defines it as a kind of tourism with a legacy of sharing tangible and intangible heritage and culture, i.e. "landscapes, buildings, collections, the arts, identity, tradition and language." (Council of Europe, 2006) Taking into consideration many European states, each of them has its own cultural heritage which attracts tourists and visitors. Thus each state is a monopoly due to uniqueness of heritage, natural resources and its genius loci.

Comparing this conception of cultural tourism with others, it results in common characteristic features of cultural tourism that will be taken as a core conception of cultural tourism for this study:

- motives for travelling are of historical and cultural value,

- shapes the identity, uniqueness and distinctiveness of each destination,

- includes art, tradition, historical assets, language, natural resources,

- well-established cultural background.

The fact that cultural tourism is and will be a driving force of tourism incomes in the future is proven by studies from New World Hope Organization (1999) and Richards (2011). Richards (2011) declares that cultural attractions in a certain destination succumb to the development of surrounding infrastructure. In Europe, the author states an example of Spain where the total number of museums has grown by $100 \%$ for past 20 years. Barcelona is taken as an evidence of cultural influence on tourism as the visitors spent $71 \%$ of their fees on cultural attractions in the city. The demand for cultural tourism is viewed as indisputable not only in Spain but in many other states as each state has a cultural value and identity. Supporting the idea of cultural tourism as a driving force, a study on Sustainable Tourism and Cultural Heritage, New World Hope Organization (1999) sees a growing potential in cultural heritage based on WTO forecast Tourism: 2020 Vision which presents cultural tourism as "one of the key tourism market segments in the future". With respect to this forecast it is predictable that motives for travelling are said to be interconnected with culture of destination. 


\section{Purpose of sustainability in culture}

Without any contribution to the conservation of cultural areas, it may happen that its uniqueness, value and heritage can gradually lose its primary purpose.

The reason for setting rules and indicators for sustainability principles in cultural tourism is backed up by authors Seçkin et al. (2013) who in their research dealt with sustainability in Ephesus area. They states that in order to preserve the Ephesus area in Greece as an important religious place for future generations "it is of utmost importance to present a balanced approach which would enable its usage in accordance with sustainability principles" (Seçkin et al., 2013).

Global Code of Ethics for Tourism depicts cultural tourism as a segment of tourism that needs to be in full compliance with sustainability. Cultural, artistic and historic heritage should succumb to the principles of sustainability since it is desirable to deliver it well- preserved to future generations (Globální etický kodex cestovního ruchu, 1999).

As a result of the quest for sustainability many guidelines to sustainable cultural tourism were written in 20th and 21th century. The titles of the most influential guides and charters are listed (Council of Europe, 2006):

- International Cultural Tourism Charter- Managing Tourism at Places of Heritage Significance, 1999

- World Tourism Organization Global Ethics for Tourism, 1999

- The Malta Declaration on Cultural Tourism: Its Encouragement and Control, Europa Nostra, 2006

- The Dubrovnik Declaration, Council of Europe, 2006

- Sustainable Cultural Tourism in Historic Towns and Cities, Guideline, Council of Europe, 2010

- The Hangzhou Declaration Placing Culture at the Heart of Sustainable Development Policies, 2013 (UNESCO, 2013)

Council of Europe in partnership with EAHTR introduced guide on sustainable cultural tourism in order to show the connection of cultural tourism with more sustainable economic and social potential, see in Fig.2. Council of Europe (2006) claims that "places and cultural tourism are not static" otherwise they would not influence each other and there would be no relationships. The principles of sustainable cultural tourism are depicted in Figure 2. 


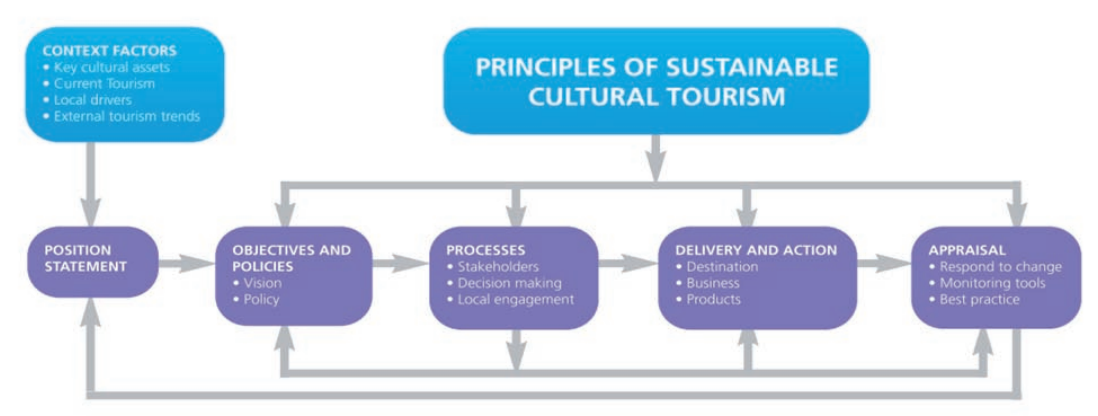

Fig. 2 - Principles of sustainable cultural tourism. Source: Council of Europe. (2006)

Cultural tourism and its components are taken as inputs into this process. As being noticed in the figure 2 , in order to get output, i.e. sustainable cultural tourism, it is suggested to establish monitoring tools that would correspond to specific chosen area of cultural tourism. It should serve as a feedback tool for monitoring previously set sustainable objectives.

\section{Cultural routes and sustainability}

Concerning cultural tourism is a type of tourism involving other subsystems; the paper will follow one specific and current segment of cultural tourism, i.e. cultural route. From a historical perspective, role of cultural routes was to memorialize various personalities and historically important cities in the worlds and richness of its past. UNESCO (1994) in Madrid defined importance of cultural routes on a conference "Routes as part of our cultural heritage". Other authorities such as International Committee on Cultural Routes (1994), European commission (2014), Council of Europe (n.d.), European institute on cultural routes WTO (2004) explain it as a rising phenomenon and current tourism product. Martorell (2003) says that "cultural values are to be preserved, for life to have a human meaning." Concerning his though and applying it on routes, cultural values are an inevitable part of cultural routes. Arising from this fact, cultural routes needs to be preserved.

Today, the importance of cultural route is even stronger due to remembering of the history along with knowledge of up - to - dated local landscape and culture. Martorell (2003) states that cultural route is a mixture of "monuments, archaeological remains, historic towns, vernacular architecture, industrial and technological heritage, public works, cultural landscapes, transportation means and other examples of the use of specific knowledge and technical skills", so it may be perceived as multidimensional type of tourism in destinations. In Europe, there exist 29 European cultural routes established by the Council of Europe in early 1987. Specifically, routes such as The Santiago de Compostela Pilgrims routes, The legacy of Al - Andalus, The Vikings Route, The route of the olive tree and others become a popular phenomenon. As the popularity has been rising, the negative impacts of visiting these routes have been rising, too. Theoretically, we may speak about environmental damage, social impacts or economic benefits of the cultural routes network that can limit the knowledge of cultural diversity. Logically, in order to guarantee a long - term perspective of cultural routes, a need for identifying sustainability indicators has been developed (European commission, 2014). The share of cultural routes in European states is 
depicted in Fig.3. It perfectly portrays the importance of solving sustainability in Europe as the percentage of share in European states is relatively high.

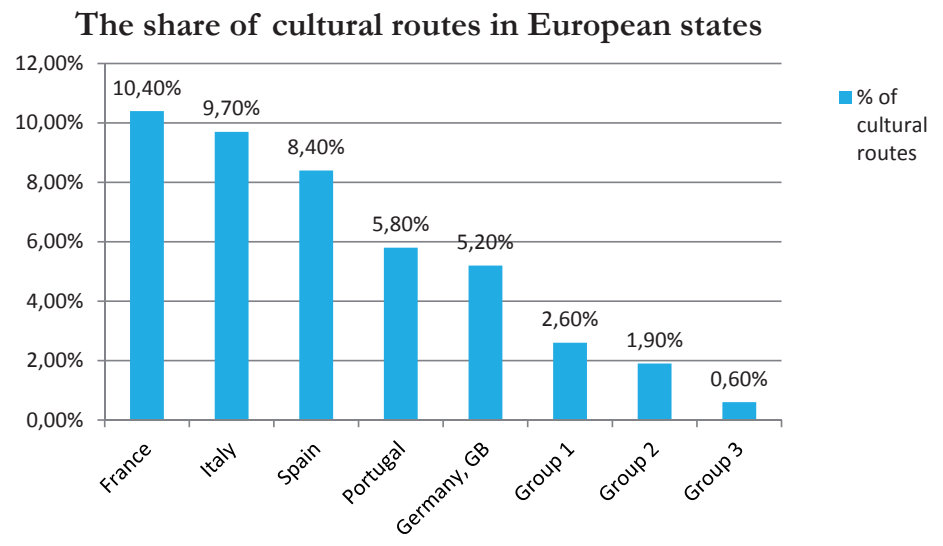

Fig. 3 - The share of cultural routes in Europe. Source: European commission (2014)

Group 1 represents states namely Belgium, Czech Republic, Greece, Norway, Poland, Sweden and Switzerland. In Group 2 the states include Algeria, Austria, Croatia, Cyprus, Lebanon, Morocco, Netherlands, Slovenia and Tunisia. Group 3 includes Albania, Argentina, Armenia, Azerbaijan, Belarus, Bulgaria, Denmark, Estonia, Jordan, Lithuania, Malta, Romania, Russian Federation, Serbia, Slovakia, Syria, Turkey and Ukraine. These three groups represent only a small percentage of share however they represent a great potential of cultural routes as a future tourism product.

\subsection{Suggested indicators for the cultural destinations}

Based on common features of cultural routes with respect to cultural tourism in general, a set of sustainability indicators is designed for better sustainable measurement. Indicators are backed up by various studies on cultural indicators of sustainable development. The following table assigns indicators for cultural routes according to different existing methodologies. Given that cultural routes are statistically worse to capture, data can be gained from tourist infrastructure businesses (WTP, 2004; European Commission, 2013). 
Tab. 1 - Suggested monitoring system for cultural destinations. Source: Elaborated based on WTO (2004); European Commission (2013); Global Tourism Sustainable Council (2013) and own research.

\section{SUGGESTED MONITORING SYSTEM FOR CULTURAL DESTINATIONS}

\section{ENVIRONMENTAL INDICATORS}

- Percentage of tourists and same day visitors using different modes of transport to arrive at the destination

- Percentage of tourism enterprises involved in climate change mitigation schemes- such as: $\mathrm{CO}^{2}$ offset, low energy, etc.

- Volume of waste recycled (percent or per resident per year

- Fresh water consumption per tourist/night

- Level of contamination of bathing water per 100 $\mathrm{ml}$ that is near cultural route

- Number of artefacts and built sites on trail and \% maintained

- Loss of flora and fauna due to tourism activity on the route

- Average travel $(\mathrm{km})$ by tourists from the previous destination to current destination

- Energy consumption per tourist night compared to general population energy consumption per person per night

- Number of tourists on trail, at one time, in a given time period or season, per year

- $\%$ of trail and margins degraded

- $\%$ of buildings considered in degraded condition

- $\%$ of old buildings on the route designated at local, national and/or World Heritage levels

- Tourist perception of cleanness in the area of routes

- Quality of natural landscape

- $\%$ of area covered by infrastructure

- Length of trails

- Existence of signage

- Interpretative materials along the trails

- $\%$ of environmental friendly transport alternatives

- Existence of recycling facility

- $\%$ of land used designed for further tourism development

- $\%$ of area damaged, or in degraded condition visible from viewpoints

\section{ECONOMIC INDICATORS}

- Number of tourist nights per month

- Direct tourism employment as percentage of total employment

- Number of newly created jobs related to the route

- $\%$ of travel agencies offering cultural routes

- Annual profit of tourism businesses near the route

- $\%$ of tourists participated on the route per month or season

- Daily spending per tourist and same day visitor in the area of cultural routes

- Relative contribution of tourism to the destination's economy based on visited cultural routes

- Number of guides

- Number of business offering trail walks

- Revenue from local craft and souvenir sales per year

- Revenue from accommodation/ year

- Visitor fees

SOCIAL INDICATORS

- Number of tourists/visitors per 100 residents)

- Percentage of men and women employed in the tourism sector with respect to cultural routes

- Percentage of visitor attractions that are accessible to people with disabilities and/or participating in recognised accessibility schemes - on the route

- Number of artefacts and built sites on trail and $\%$ maintained

- $\%$ of local residents who believe they benefit from the trail

- Number of complaints/compliments per year from tourists participated on cultural route

- $\%$ of visitors satisfied with the transport accessibility to route (bicycle, foot, car)

- Number of historical sights available and open for visitors at the route 


\subsection{Characteristic features of mountain destinations concern to sustainable development}

We can find the definition of tourism mountain destination and its characteristics mainly in the geographic typologies of tourism destinations. Slovak authors (Kuklica a kol., 1965; Mariot 1983, 2001; Horák a kol., 1985; Kopšo a kol., 1989; Gúčik, 2011; Gúčik \& Pěč, 2011) pay attention mainly to geographic and climatic requirements, which is from the sustainable point of view not sufficient. Kopšo, 1992 \& Patúš, 2004 focus mainly on the secondary offer, as a basic precondition for tourism development. The common feature of the foreign authors' definitions of mountain destinations (Flagestad, Hope, 2001; Medlik, 2003; Weiermair, 2004; Nepal \& Chipeniu, 2005; Matto \& Scott, 2008; Bourdeau, 2009; Keller, 2012; Kuščer, 2013) is in the identification of the activities that are carried in a destination and not geographic conditions. The shortcomings of these definitions lies in the fact that mountain destinations are explained using the descriptive method, without quantitative characteristics.

In terms of climatic conditions and geographic features by the examination of the approaches of domestic and foreign authors, we have defined a set of appropriate preconditions for mountain destinations in Slovakia:

- transport accessibility of destination (Gúčik, 2011),

- primary supply (forest and meadows) in such quantity and quality, which is attractive for the visitors (Kopšo, 1992; Patúš, 2004; Gúčik \& Pěč, 2011);

- adequate infrastructural facilities, which allow a stay in the destination and provision of services (Patúš, 2004; Gúčik, 2011);

- possibilities to participate on the leisure activities typical for a mountain destination (Medlik, 2003; Patúš, 2004; Keller, 2012, Maráková, Holúbeková, Makovník \& Gajdošík, 2013);

- Active destination management organization or a core business entity (Kämpf \& Weber, 2005; Flagestad \& Hope, 2012, Maráková, Holúbeková, Makovník \& Gajosšík, 2013

The natural environment is a prerequisite for development of tourism in a mountain destination. We agree with the opinion of Kučerová (1999), who stressed that tourism does not have unlimited possibilities for growth because it is dependent on natural resources. In some cases, the environment is so unique that it is protected by various degrees of conservation. Furthermore Keller (2012) stresses that the natural environment of mountain resorts is easy disruptive and therefore all activities that are carried out in it should respect it. Thus the management of a mountain destination must before any decision about its further development take into account the fact that the impact of various activities disturbs the natural conditions. Management of mountain destination must emphasize not only on their natural environment, but also on their social and economic balance (all three pillars of sustainable development).

When defining the principles of sustainable tourism development in mountain destinations we build on the work of Matt \& Scott (2008), who created eight principles for the mountain destinations in an effort to protect the resources to comply with: 
- Socio-ecological system integrity: Mountain destination needs to pursue opportunities that reduce human-induced stresses on biophysical systems. A limit must be set on quantitative growth.

- Livelihood sufficiency and opportunity: Mountain destinations services should be provided in ways that do not compete directly with the local business community and in fact stimulate opportunities for local income generation.

- Intra-generational equity: Mountain destination has a responsibility to ensure that employees are provided with affordable housing and should offer a wide range of accommodation in order to serve different economic classes of visitor.

- Inter-generational equity: There is acknowledgement from the mountain destination industry to take action on sustainability in order to allow for skiing to be enjoyed by future generations as well as an acknowledgement of the moral responsibility to take action for the well-being of future generations.

- Resource maintenance and efficiency: In a mountain destination should be used energy, water and materials in an efficient manner.

- Socio-ecological civility and democratic governance: Decision-making on sustainability must be addressed in a systematic and integrated way.

- Precaution and adaptation: Research is important to understanding the environmental and social processes that underpin the social and environmental carrying capacity related to the mountain destination's operations.

- Immediate and long-term integration: Decision-making on sustainability must be addressed in a systematic and integrated way.

Based on the specificities of mountain destinations we propose a set of specific indicators for ensuring sustainable development in mountain destinations.

\subsection{Suggested indicators for the mountain destinations}

Indicators, on which it is possible to assess the impact of tourism on the sustainability of destination, were divided into three groups, according pillars of sustainability (environmental, social and economic). Management of a mountain destination has to monitor the mountain resort indicators and compare their evolution over time; they just have the reporting ability of the actual impact of tourism on sustainable development. 
Tab. 2 - Suggested monitoring system for mountain destinations. Source: Elaborated based on WTO (2004), European Commission (2013), Global Tourism Sustainable Council (2013) and own research.

\section{SUGGESTED MONITORING SYSTEM FOR MOUNTAIN DESTINATIONS}

\section{ENVIRONMENTAL INDICATORS}

- Existence of land use planning and regulative

- Existence of building regulations and environmental impact assessment procedure

- Modes of public and environmental friendly transport to reach the destination (frequency, capacity, occupancy rates, price)

- $\%$ of sites and tourism enterprises accessible by public and environmental friendly transport

- $\%$ of visitors arriving by means other than car or plane

- \% visitor use of public and environmental friendly transport when in the destination

- $\%$ of enterprises with recognized environmental certification

- Environmental state of selected sites

- Number and size of protected sites and land area

- Percentage of selected types of precious landscape area (e.g. ski slope) that is built upon

- Number of buildings, commercial signs, infrastructure, that can be seen from viewpoints, along scenic roads

- $\%$ of area with traditional land use

- $\%$ of ski lifts in eroded conditions

- $\%$ of enterprises reporting that they are taking

\section{ECONOMIC INDICATORS}

- Annual profit of tourism businesses

- Profitability of tourism enterprises

- Total visitor arrivals per month

- Average length of stay

- Average spending per visitor

- Annual average occupancy of accommodation (\%)

- Local spending (or GDP) generated by tourism

- Number of tour operators serving the destination

- Amount of revenue raised from tourism and used for the maintenance of public areas and infrastructure

\section{SOCIAL INDICATORS}

- Total employment in sector as percent of total employment

- $\%$ of tourism jobs that are seasonal only

- $\%$ residents indicating that they are satisfied with local impact of tourism

- $\%$ residents identifying that they are directly benefiting from local tourism and \% believing that it adds to overall quality of life

- $\%$ of products sold in shops produced locally

- $\%$ of shops and restaurant selling local products

- Existence of special brands, labels for local products

- $\%$ of business establishments open all year

- $\%$ of jobs occupied by local residents

- Local unemployment rate in season in comparison to off-season

- Number of incidents reported

- Number of attractions and facilities with special access for people with mobility concerns

- Changes in prices of goods, properties and housing

- Number of residents who have left the destination in the previous years

- Number of immigrants taking tourism jobs in the past year

The monitoring system is designed for the management of mountain destinations to help them to decide on planning and strategy formulation in order to fulfill the criteria of sustainable development. The social indicators focused on raising the living standards of local inhabitants and improving their relationship with tourists. Economic indicators propose the ways for maximiz- 
ing the economic impacts of tourism in mountain destinations, while the environmental indicators protect the fragile natural environment.

\section{CONCLUSION}

For ages cognitive process becomes a part of tourism activities. But what if there is nothing more to experience in a destination. For this reason, in order to preserve natural, historical and social sources, tourism experts deal with sustainable development in destinations. Cultural and mountain destinations are two areas where sustainability needs to be measured as it serves as environmental, social and economic preservation of destination. Experts in sustainable tourism have defined various principles and indicators that might be applied to practice. However, for cultural and mountain destinations, a methodology for setting and designing sustainable tourism indicators lacks a list of environmental, social and economic indicators for two specific areas, i.e. cultural routes and mountain destinations.

Referable to the literature review, critically, most of the previously mentioned authors do not provide elaborated instructions on how to exactly measure three pillars of sustainability of a destination. Based on the knowledge from the literature review, the integration of theoretically defined indicators with their practical application the on cultural and mountain destinations have also been missing.

Therefore the added value of the paper lies in the creating of a specific monitoring system focused on cultural and mountain destinations. However the further research should be aimed at other types of tourism destinations and their specific conditions of sustainable development.

\section{Acknowledgement:}

This paper was created at the Tomas Bata University in Zlin and was supported by Project No. IGA/ FaME/2015/035: Economic sustainability of tourism companies.

\section{References}

1. Bell, S., \& Morse, S. (2008). Sustainability Indicators: measuring the immeasurable. London: Earthscan Publications.

2. Bossel, H. (1999). Indicators for sustainable development: theory, method, applications. Winnipeg: International Institute for Sustainable Development.

3. Bourdeau, P. (2009). Mountain tourism in a climate of change. In R. Jandl. et al. Global Change and Sustainable Development in Mountain Regions (pp. 99-136). Innsbruck: Innsbruck University Press.

4. Bramwell, B., \& Lane, B. (2010). Sustainable tourism and the evolving roles of government planning. Journal of Sustainable tourism, 18 (1), 1-5. http://dx.doi.org/10.1080/09669580903338790

5. Butler, R. (1998). Rural Recreation and Tourism. In: B. Ilbery (Ed.), The Geography of Rural Change. Harlow: Addison Wesley Longman.

6. Byrd, E. T. (2007). Stakeholders in sustainable tourism development and their role: applying stakeholder theory to sustainable development. Tourism Review, 62 (2), 6-13. http/ dx.doi.org/10.1108/16605370780000309 
7. Coccossis, H. (2008). Cultural heritage, local resources and sustainable tourism. International Journal of Services Technology and Management. 10 (1), 8-14. http://dx.doi.org/10.1504/ IJSTM.2008.020340

8. Council of Europe. (2006). European Association of Historic Towns and Regions. Sustainable Cultural Tourism in Historic Towns and Cities. Retrieved May 20, 2014, from: http://urbact. eu/fileadmin/corporate/doc/EAHTR_guide.pdf

9. Council of Europe. n. d. Impact of European Cultural Routes on SME's innovation and competitivness. Provisional edition. Retrieved March 10, 2014, from http://www.coe.int/t/ dg4/cultureheritage/culture/Routes/StudyCR_en.pdf.

10. Craik, J. (1995). Are there cultural limits to tourism? Journal of Sustainable Tourism 3 (2), 87-98. http://dx.doi.org/10.1080.09669589509510713

11. Daly, H. (1996), Beyond Growth: The Economics of Sustainable Development, Beacon Press, Boston.

12. Division for Sustainable Development. (2001). Indicators of sustainable development: Framework and methodologies. Background paper no.3. Commission on Sustainable Development. Ninth Session. New York. Retrieved from: http://www.un.org/esa/sustdev/csd/csd9_indi_bp3. pdf

13. European commission. (2014). Cultural tourism. Retrieved March 10, 2014, from: http:// ec.europa.eu/enterprise/sectors/tourism/cultural-routes/index_en.htm

14. European Institute of Cultural Routes. Web-sites-Cultural routes of the Council of Europe. Retrieved May 10, 2014, from: http://www.via-regia.org/kulturstrasse/pdf/websites.pdf

15. European Union. (2013). European Tourism Indicator System TOOLKIT for Sustainable Destinations. DG Enterprise and Industry.

16. Farrel, B., \& Twining-Ward, L. (2005). Seven steps towards sustainability: tourism in the context of new knowledge. Journal of Sustainable Tourism, 31 (2), 274-295. http://dx.doi. org/10.1080/09669580508668481

17. Flagestad, A., \& Hope, C. A. (2001). Strategic success in winter sports destinations: a sustainable value creation perspective. Tourism management, 22 (5), 445-461. http://dx.doi. org/10.1016/S0261-5177(01)00010-3

18. Garrod, B., \& Fyall, A. (1998). Beyond the rhetoric of sustainable tourism? Tourism management, 19 (3), 199-212. http://dx.doi.org/10.1016/S0261-5177(98)00013-2

19. Global Sustainable Tourism Council. (2012). Global Sustainable Tourism Criteria for Destinations. Retrieved March 25, 2014, from: http://www.gst-council.org/sustainable-tourism-gstccriteria/criteria-fordestinations.html

20. WTO. (1999). Globálni etický kodex cestovního ruchu. Retrieved from: http://www.edenczechtourism.cz/files/czech_code_of_ethics.pdf

21. Gúčik, M. (2010). Cestovný ruch - úvod do štúdia. Slovensko - švajčiarske združenie pre rozvoj cestovného ruchu.

22. Gúčik, M. (2011). Cestovný ruch-Politika a ekonómia. Slovensko-svajciarske združenie pre rozvoj cestovného ruchu. 
23. Gúčik, M., \& Pěč, J. (2011). Klasifikácia stredísk cestovného ruchu na Slovensku. Ekonomická revue cestovnébo ruchu, 44, (1). 47-53.

24. Hardy, A., Beeton, R. J., \& Pearson, L. (2002). Sustainable tourism: An overview of the concept and its position in relation to conceptualisations of tourism. Journal of Sustainable Tourism, 10(6), 475-496. http://dx.doi.org/10.1080/09669580208667183

25. Horák, V. et al. (1985). Typológia stredísk cestovného ruchu a rekreácie. Bratislava: ERPO.

26. International Committee on Cultural Routes. (1994). Retrieved May 12, 2014, from: http:// www.icomos-ciic.org/INDEX_ingl.htm

27. Keller, P. F. (2012). Changing Paradigm in Sustainable Mountain Tourism: A critical analysis from a global perspective. EURAC Research. Conference on Changing Paradigms of Sustainable Mountain Tourism, Brixen. Retrieved November 28, 2012, from: http://www.eurac.edu/en/ research/institutes/regionaldevelopment/conferences/sustmnttourism/Presentations.html

28. Kopšo, E. et al. (1989). Materiálno-technická quákladña cestovného ruchu a spoločnébo stravovania. Bratislava: Slovenské pedagogické nakladatel'stvo.

29. Kopšo, E. et al. (1992). Geografia cestovného ruchu. Bratislava: Slovenské pedagogické nakladatel'stvo.

30. Kučerová, J. (1999). Trvalo udržatel’ný rozvoj cestovnébo ruchu. Banská Bystrica: Univerzita Mateja Bela.

31. Kučerová, J. (2012). Innovations of selected marketing instruments in mountain resorts - sustainability or market driven forces? EURAC Research. Conference on Changing Paradigms of Sustainable Mountain Tourism, 2012, Brixen. Retrieved November 28, 2014, from: http://www. eurac.edu/en/research/institutes/regionaldevelopment/conferences/sustmnttourism/ Presentations.html

32. Kuklica, J. et al. (1965). Metodické pokyny pre výstavbu komplexných stredísk cestovného ruchu a rekereácie. Praha: Vydavatelství obchodu.

33. Kuščer, K. (2013). Determining Factors of Mountain Destination Innovativeness. Journal of Vacation Marketing, 19 (1), 41-54. http://dx.doi.org/10.1177/1356766712461404

34. Lawn, P. (2006). Sustainable development indicators in ecological economics. Great Britain: MPG Books Ltd.

35. Lozano- Oyola, M., Blancas, J.F., González, M. \& Rafael Caballero. (2012). Sustainable tourism indicators as planning tools in cultural destinations. Spain: Malaga University. Ecological Indicators, 18, 659-675. http://dx.doi.org/10.1016/j.ecolind.2012.01.014

36. Mariot, P. (1983). Geografia cestovnébo ruchu. Bratislava: Veda.

37. Martorell Carreño, A. (2003). Cultural routes: Tangible and intangible dimensions of cultural heritage. In: 14th ICOMOS General Assembly and International Symposium: 'Place, memory, meaning: preserving intangible values in monuments and sites'. Victoria Falls, Zimbabwe.

38. Matto, T. D., \& Scott, D. (2008). Sustainable Ski Resort Principles. In GÖSSLING, S. a kol. Sustainable Tourism Futures. Perspectives on Systems, Restructuring and Innovations. (pp. 131-151). New York: Routledge. 
39. Medlik, S. (2003). Dictionary of travel, tourism and hospitality. Oxford: Elsevier Science.

40. Moldan, B. (2003). (Ne)udř̌itelný rozvoj. Ekologie - broz̧ba i naděje. Praha: Karolinum.

41. Nepal, S., \& Chipeniu, R. (2005). Mountain Tourism: Toward a Conceptual Framework. Tourism Geographies, 7 (3), 313-333. http://dx.doi.org/10.1080/14616680500164849

42. New World Hope Organization. (1999). Sustainable Tourism and Cultural Heritage: A Review of Development Assistance and Its Potential to Promote Sustainability. Retrieved March 18, 2014, from: http://www.nwhf.no/files/File/culture_fulltext.pdf

43. Ngamsomsuke, W., Hwang, T. \& Chi-Jui Huang. (2011). Sustainable Cultural Heritage Tourism Indicators. International Conference on Social Science and Humanity IPEDR. Vol. 5. Sinagpore: IACSIT Press.

44. Nováček, P. (2010). Indikátory udržitelného rozuvoje. Retrieved from: http://www.futurologia. sk/pdf/novacek_udrzitelny_rozvoj_indikatory.pdf

45. OECD. (2002). Towards sustainable household consumption. Paris: Observer.

46. Patúš, P. (2004). Problémy manažmentu strediska cestovného ruchu. Banská Bystrica: Univerzita Mateja Bela.

47. Pforr, C. (2001). Concepts of sustainable development, sustainable tourism and ecotourism: definitions, principles and linkages. Scandinavian Journal of Hospitality and Tourism, 1(1), 68-71. http://dx.doi.org/10.1080/15022250127788

48. Rio D., \& Nunes, L.M. (2012). Monitoring and evaluation tools for tourism destinations. Tourism Management Perspectives, 4, 64-66. http://dx.doi.org/10.1016/j.tmp.2012.04.002

49. Richards, G. (2011) Cultural tourism trends in Europe: a context for the development of Cultural Routes. In: Khovanova - Rubicondo, K. (ed.), Impact of European Cultural Routes on SME's innovation and competititveness (pp. 21-39). Strasbourg: Council of Europe Publishing.

50. Roberts, S. \& Tribe, J. (2008). Sustainability Indicators for Small Tourism Enterprises - An Exploratory Perspective. Bridgetown, Barbados: The University of the West Indies. UK: University of Surrey. Journal of Sustainable Tourism. 16 (5). doi: 10.2167/jost579.0

51. Eser, S., Dalgin, T., \& Çeken, H. (2013). Culture Tourism as a Sustainable Tourism Type: The Ephesus Example. Social Sciences, 79(1), 17-22. http://dx.doi.org/10.5755/j01. ss.79.1.4071

52. Sharpley. R. (2000). Tourism and sustainable development: exploring the theoretical divide. Journal of Sustainable Tourism, 8 (1), 1-19. http://dx.doi.org/10.2167/jost579.0

53. Sheehan, L. R., \& Ritchie, J. R. B. (2005). Destination stakeholders, exploring identity and saliance. Annals of Tourism Research, 32 (3), 711-734. http://dx.doi.org/10.1016/ j.annals.2004.10.013

54. Stebbins, R.A. (1996). Cultural Tourism as Serious Leisure. Canada: University of Calgary. 23(4), 948- 950. Annals of Tourism Research. http://dx.doi.org/10.1016/0160-7383(96)00028-X

55. UNESCO. (1994). Routes as part of our cultural heritage: Report on the meeting of experts. Retrieved April 20, 2014, from: http://whc.unesco.org/archive/routes94.htm 
56. UNESCO. (2013). The Hangshou Declaration: Placing Culture at the Heart of Sustainable Development Policies. China. Retrieved May 15, 2014, from: http://www.unesco.org/new/ fileadmin/MULTIMEDIA/HQ/CLT/images/FinalHangzhouDeclaration20130517.pdf

57. United Nations Sustainable Development. (1992). United Nations Conference on Environment \& Development. Agenda 21. Brazil: Rio de Janeiro. Retrieved May 28, 2014, from : http:// sustainabledevelopment.un.org/content/documents/Agenda21.pdf

58. United Nations. (2001). Managing Sustainable Tourism Development. Bangkok: United Nations publication.

59. UNWTO. (2012). Tourism Towards 2030. Advanced release. 54th meeting of the UNWTO Commission for Europe. Georgia. Retrieved May 28, 2014, from: http://dtxtq4w60xqpw. cloudfront.net/sites/all/files/pdf/item_4_d.pdf

60. Waldron, D. \& Williams, P. W. (2002). Steps towards sustainability monitoring: the case of the resort municipality of Whistler. In: Harris, R., Griffin, T. \& Williams, P. (Eds.), Sustainable Tourism: a global perspective (pp. 180-194). Oxford: Elsevier. http://dx.doi.org/10.1016/B978-0-75068946-5.50015-0

61. Weiermair, K. 2004. Product improvement or innovation: what is the key to success in tourism? OECD. pp. 11. Retrieved November 21, 2014, from: https://www1.oecd.org/ cfe/ tourism/34267947.pdf

62. World Commission on Environment and Development. (1987). Our Common Future. United Nations. Retrieved March 20, 2013, from: http://conspect.nl/pdf/Our_Common_FutureBrundtland_Report_1987.pdf

63. World Tourism Organization. (1996). What Tourism Managers need to know: A practical guide to the development and use of indicators of Sustainable development. Ottawa: Consulting and Audit Canada.

64. World Tourism Organization. (2004). Indicators of Sustainable Development for Tourism Destinations: A Guidebook. Spain: World Tourism Organization.

65. Česko. (1991). Zákon č. 17/1992 Sb. Retrieved from: http://www.tzb-info.cz/pravnipredpisy/zakon-c-17-1992-sb-o-zivotnim-prostredi

\section{Contact information}

Ing. Zuzana Jurigová

Faculty of Management and Economics

Tomas Bata University in Zlin

Nám. T.G.Masaryka 5555, 76001 Zlín

e-mail:zjurigova@fame.utb.cz

Ing. Zuzana Lencsésová

Faculty of Economics

Matej Bel University

Tajouského 10, 97590 Banská Bystrica

e-mail:zuzana.lencsesova@umb.sk 